\title{
The Effects of Phonetic Duration on Loanword Adaptation: Mandarin Falling Diphthong in Chinese Korean
}

\author{
Na-Young Ryu ${ }^{1}$, Yoonjung Kang ${ }^{2,3}$ \& Sungwoo $\mathrm{Han}^{4^{\dagger}}$ \\ ${ }^{1}$ Pennsylvania State University, ${ }^{2}$ University of Toronto Scarborough, \\ ${ }^{3}$ University of Toronto, ${ }^{4}$ Inha University
}

\begin{abstract}
This study examines how Mandarin falling sonority diphthongs are adapted to a Chinese Korean dialect. It investigates how the subtle phonetic conditions of the source language affect adaptation, and if and how those phonetic effects differ in established loanwords compared to the on-line adaptation of novel loan forms. We found that in this bilingual population, while the Mandarin diphthongs are usually adapted as monophthongs, obeying the native phonological restriction against falling diphthongs, the retention of the input diphthongs in violation of the native constraint is also quite common. Additionally, we found that the choice of the monophthong vs. diphthong realization is strongly affected by the input phonetic duration and in particular, the durational difference among the different tones is robustly reflected in the adaptation patterns.
\end{abstract}

Keywords: phonetic and phonological adaptation, loanwords, Mandarin falling diphthongs, Chinese Korean, tones

\section{Introduction}

When foreign words are borrowed into a language, they often undergo transformations in order to comply with the phonological constraints of the borrowing language. A relevant example comes from Standard Seoul Korean, which does not have diphthongs with falling sonority. When Mandarin (MA) words with falling diphthongs /ai, au, ei, ou/ are borrowed into Standard Korean (SK), the

\footnotetext{
* The authors would like to thank three anonymous reviewers for their suggestions that improved the paper. We would also like to thank Professor Sun Ying at Liaoning University, Professor Yunyan Luo at Beijing Foreign Studies University, and Yuanyang Song for their invaluable help during the data collection process, Sung-Geol Kim for help with stimulus preparation, Hyoung-Seok Kwon for help with data analysis, Professor Oh Sung-Ae at the Ocean University of China and the audience members at LabPhon15 and the Workshop on the Phonetics and Phonology in Loanword Adaptation for comments on earlier versions of the paper. The work was supported by the Insight Grant from the Social Science and Humanities Research Council of Canada.

† Corresponding author: nayoung.ryu@psu.edu
} 
diphthongs are generally adapted as a heterosyllabic vowel sequence as in MA mao2 ze2 dong1 [máu tş́ tōy], 'Mao Zedong'1)> SK [ma.o.ts*^.tụ]. The current study examines how these Mandarin diphthongs are adapted in Chinese Korean (CK), the variety of Korean spoken by the ethnic Koreans living in China, where the level of community and individual bilingualism is high.

To anticipate the results of our study, we find that Chinese Korean also adapts the Mandarin diphthong to avoid illicit falling diphthongs, but the repair of choice is monophthongization through vowel coalescence, in which two segments of a Mandarin diphthong coalesce into a monophthong, as in MA zao3 can1 [tsău tshān] 'breakfast' > CK /ts*o.tshan/. That is, the Mandarin diphthong /au/ is replaced with Chinese Korean monophthong /o/. More interestingly, we also observe that the Mandarin diphthongs are frequently retained as diphthongs in Chinese Korean, as in MA tao3 mei2 [thău méi] 'bad luck' > CK [ [t*o.méi]. In this study, we examine how bilingual Chinese Korean speakers produce Mandarin loans with original falling diphthongs and how they adapt novel loans.

This study has two goals. The first is to examine the role of input language phonetics in adaptation (e.g., Silverman, 1992; Yip, 1993; Kenstowicz, 2003; Y. Kang, 2003). In particular, we explore how the phonetic duration of Mandarin input vowels affects adaptation. We hypothesize that the longer the duration of the input vowel is, the higher the rate of diphthongal adaptation would be. In other words, if the adaptation is sensitive to the input duration, we expect a higher rate of diphthongal adaptation in phonological contexts where the vowels are longer. To test our hypothesis, we consider a number of phonetic factors such as the Mandarin tone of the input diphthongs (Tone $1 \sim$ Tone 4 ), the target syllable position within the word (initial vs. final), and the interaction between the two. Previous studies found that Mandarin tones systematically differ in duration, in such a way that and Tone 3 is the longest and Tone 4 is the shortest (Xu, 1997; Wu \& Kenstowicz, 2015). We predict that the longer the tones are, the higher the rate of diphthongal adaptation would be. In terms of the word position, since syllables are lengthened in word-final position in Mandarin (Barnes, 2006; Chen, 2006), we expect that diphthongal adaptations are more likely to appear in the final syllable than in word-initial syllable. Finally, we look at the interaction between tone and word position. We predict that tone effects depend on the word-position because Tone 3 is known to shorten substantially in a non-final position in Mandarin (Xu, 1997;

1) In this paper, we use the pinyin tone diacritics to indicate tones in the phonetic representation and use the tone numbers in Pinyin instead of the diacritics for readability. 
Yip, 2002; Wu \& Kenstowicz, 2015).

Second, we compare the adaptation patterns between established loanwords and on-line adaptation of Mandarin words. Investigating on-line adaptations has an advantage in that we can examine the speaker's productive knowledge of crosslanguage mapping. Established loanwords are reflections of speakers' lexical knowledge, which is, in turn, the result of the accumulation of collective history of adaptation and subsequent revisions at the community level. Thus, they may contain idiosyncrasies and historical remnants of archaic patterns that are no longer productive. On-line adaptation, on the other hand, reveals speakers' productive knowledge regarding the cross-language correspondence in action. This knowledge may draw from the generalizations of the existing lexicon (Simonović, 2017) but may not necessarily be isomorphic to them. In particular, we are interested in whether and how bilingual speakers accurately internalize the effects of subtle phonetic details in established loans and productively extend them to on-line loanword adaptation.

The paper is organized as follows. Section 2 reviews previous studies on loanword phonology. In Section 3, we present the background of the minority Koreans living in northeast China. This section also gives a brief overview of Mandarin and Chinese Korean phonology. Section 4 shows the methods and results of this study, which explores how bilingual Chinese Korean speakers produce established Mandarin loanwords, which are frequently used in Chinese Korean, and also how they adapt novel loanwords in an on-line adaptation task. Section 5 discusses several issues that arise from the present analysis. Section 6 concludes the paper.

\section{Previous Studies of Loanword Phonology}

There are two different views on the role of input language phonetics in loanword phonology: the phonological stance model (Paradis \& LaCharité, 1997; LaCharité \& Paradis, 2005; Paradis \& Tremblay, 2009) and the perceptual stance models (Silverman, 1992; Yip, 1993; Kenstowicz, 2003; Peperkamp \& Dupoux, 2003; Y. Kang, 2003; Boersma \& Hamann, 2009).

Paradis \& LaCharité (1997) proposed that loanword adaptation is inherently phonological, and borrowers are bilinguals who have access to the phonology of both the source and the borrowing languages. Based on 12 large corpora of English and French loanwords in several different languages, they argue that a phonological 
transformation, rather than phonetic approximation, is the principal mechanism of loanword adaptation. For instance, when English loanwords are adapted into French, English $/ \mathrm{b} /$ is preserved as $/ \mathrm{b} /$, despite the phonetic differences that make it acoustically closer to French /p/, because in both languages, /b/ is phonologically represented with the same feature combination, that of a voiced labial stop. In other words, if a given L2 phonological category (i.e., feature combination) does not exist in L1, this L2 category will be replaced by the closest phonological category in L1, even if the L1 inventory contains an acoustically closer alternative (Paradis \& LaCharité, 1997; LaCharité \& Paradis, 2005).

According to the perceptual models of adaptation, on the other hand, loanword adaptation is sensitive to the subphonemic phonetic information of the input structure (Silverman, 1992; Kenstowicz, 2003; Peperkamp \& Dupoux, 2003; Boersma \& Hamann, 2009). While differing in the specific mechanisms by which the phonetic information affects the adaptation, they agree that non-contrastive phonetic details of the input and the borrowing language may affect the adaptation. For instance, Y. Kang (2003) examined vowel insertion patterns following English postvocalic word-final stops in English loanwords in Korean. Korean stops are obligatorily unreleased when they are in word-final position. She observed that word-final stops in English are more frequently released after a tense vowel than after a lax vowel, and that vowel epenthesis is more likely to appear in Korean loanwords when the pre-final vowel in the English source words is tense. For example, the English word stick with a lax vowel is adapted as [si.t $t^{\text {hik] }}$ while the English word mic(rophone) with a tense vowel is realized as [ma.i. $\mathrm{k}^{\mathrm{h}} \mathrm{i}$ ] in Korean. She argued that the motivation for vowel insertion in this position is to increase the perceptual similarity between the English input and the Korean output.

Hsieh et al. (2009)'s investigation of the adaptation of English coda nasal in Mandarin Chinese presents an example where the perceptual similarity, rather than the phonological contrastiveness, determines the adaptation pattern. In Mandarin, the coda nasal place distinction between $/ \mathrm{n} /$ and $/ \mathrm{y} /$ is contrastive and conditions the allophonic variation between front and low back vowels ([a] vs. [a]). They examined the adaptation of coda nasals preceded by a low vowel in English and found that the choice between [n] and [ $\mathrm{n}$ ] is determined by the front vs. back nature of the preceding vowel in the English source words, rather than the place of articulation of nasal (e.g., clan [klæn] > MA [ke.lan] vs. crown [kıaun] > MA [ke.lan]). In the vowel + nasal sequences, the vowel, which is phonetically more salient, has an impact on the realization of adaptation. This is the case despite the 
fact that coda nasal place distinction is contrastive in Mandarin while the backness of low vowels is a non-contrastive allophonic distinction in Mandarin. They, therefore, concluded that phonetic salience is a significant factor in loanword adaptation that can outweigh a phonologically contrastive feature of the borrowing language. In this study, we will present the results of Chinese Korean loanword adaptation and examine how the phonetic duration of the Mandarin vowel, which is not contrastive in Mandarin or Korean, affects the adaptation patterns.

\section{Backgrounds}

\subsection{Ethnic Korean population in China}

Koreans are the thirteenth largest ethnic minority in China, with a total of roughly 1.9 million people. Most live in northeast China, particularly the Yanbian Korean Autonomous Prefecture, with the rest residing in Inner Mongolia and large cities such as Beijing, Shanghai and Qingdao (Jin, 2008). The majority of ethnic Koreans living in China today are descendants of immigrants who migrated from Korea between the mid 19th century and the mid 20th century. The current work focuses on Mandarin loanwords spoken by Chinese Korean bilinguals living in Dandong, a city in the Liaoning Province of China, on the border between China and North Korea. Dandong has a Korean population of around 20,000 (Cui, 2011). The majority of ethnic Koreans in China are bilingual, but the dominant language is shifting from Korean to Mandarin in many communities in China (Choi, 2001; Jin, 2008; Han, 2011, 2014). In particular, Schertz et al. (2017) found that younger speakers in Dandong use Korean less and consider themselves to be less proficient in Korean than in Mandarin, while older speakers are dominant in Korean and have relatively low Mandarin proficiency.

\subsection{Chinese Korean vowels}

Chinese Korean is a branch of Korean, spoken by ethnic Koreans residing in China. According to Jin (2008), Chinese Korean has a vowel system similar to Standard Korean spoken in Seoul, except that it retains some of the contrasts that are being lost in Standard Korean. The vowel system of Korean has ten monophthongs, as provided in Table 1. In most South Korean dialects of Korean, 
the contrasts between the low and mid front vowels ([e] vs. [ع]) are lost, and the front rounded vowels are realized as a diphthong ([wi] or [we]) (H. Kang, 1997; Silva \& Jin, 2008; Eychenne \& Jang, 2015; Yoon et al., 2015). In contrast, Chinese Korean, the variety spoken in Dandong, retains the [e] vs. [ع] contrast and the front rounded vowel [y] (Jin, 2008; Kang et al., 2015, 2016).

Table 1. Inventory of Korean monophthongs (Adapted from Lee \& Ramsey 2011)

\begin{tabular}{ccccc}
\hline & Front unrounded & Front rounded & Back unrounded & Back rounded \\
\hline \hline High & $\mathrm{i}$ & $(\mathrm{y})$ & $\dot{\mathrm{i}}$ & $\mathrm{u}$ \\
Mid & $\mathrm{e}$ & $(\varnothing)$ & $\Lambda$ & $\mathrm{o}$ \\
Low & $(\varepsilon)$ & & $\mathrm{a}$ & \\
\hline
\end{tabular}

As for diphthongs, there are ten diphthongs in Standard Korean, nine on-glide diphthongs and one off-glide diphthong, as presented in Table 2. Standard Korean has no falling diphthongs, except for / ij/ with a questionable status (H. Kang, 1997; Ahn \& Iverson, 2007). This diphthong is a remnant of a system of $\mathrm{j}$-final diphthongs from Late Middle Korean, which subsequently monophthongized to create the front vowel series in Modern Korean, as in $\Lambda \mathrm{j}>\mathrm{e}$, aj $>\varepsilon$, uj $>\mathrm{y}$, and oj $>\varnothing$ (Lee \& Ramsey, 2011). The status of off-glide diphthongs in Chinese Korean is less clear, and the archaic diphthongal pronunciation long lost in Standard Korean is reported in some words as in $[\mathrm{kaj}] \sim[\mathrm{k \varepsilon}]$ 'dog' and $[\mathrm{k} \wedge \mathrm{j}] \sim[\mathrm{ke}]$ 'crab' (Jin, 2008).

Table 2. Diphthongs in Standard Korean (Adapted from Shin et al. 2012: 109)

\begin{tabular}{|c|c|c|c|c|c|c|}
\hline \multicolumn{6}{|c|}{ On-glide diphthongs } & \multirow{2}{*}{$\begin{array}{c}\text { Off-glide diphthongs } \\
\text { (ij) }\end{array}$} \\
\hline- & - & $\mathrm{ju}$ & wi & - & - & \\
\hline je & $\mathrm{j} \Lambda$ & jo & we & $\mathrm{w} \Lambda$ & - & \\
\hline (je) & ja & & $(\mathrm{w} \varepsilon)$ & wa & & \\
\hline
\end{tabular}

\subsection{Mandarin vowels and tones}

According to most analyses (Cheng, 1973; Duanmu, 2007; Lin, 2007), Mandarin has five phonemic vowels /i, $\mathrm{y}, \partial, \mathrm{u}, \mathrm{a} /$, as seen in Table 3. There are four falling sonority diphthongs /ai, ei, au, ou/ in Mandarin. Examples are provided in Table 4. 
Table 3. Vowel inventory of Mandarin (Lin 2007: 82)

\begin{tabular}{ccccc}
\hline & Front & Front & Central & Back \\
\hline \hline High & $\mathrm{i}$ & $\mathrm{y}$ & & $\mathrm{u}$ \\
Mid & & & $\partial$ & \\
Low & $\mathrm{a}$ & & & \\
\hline
\end{tabular}

Table 4. Examples of Mandarin diphthongs (Lin 2007: 68)

\begin{tabular}{cccccccc}
\hline & IPA & Pinyin & Gloss & & IPA & Pinyin & Gloss \\
\hline \hline /ai/ & {$[$ khāi] } & kai1 & 'to open' & /au/ & {$[\mathrm{kāu}]$} & gao1 & 'high' \\
/ei/ & {$[$ pēi] } & bei1 & 'cup' & /ou/ & {$[$ tōu $]$} & dou1 & 'all' \\
\hline
\end{tabular}

The off-glides of the diphthongs usually fall short of the high vowel position of [i] and [u] in actual articulation. Specifically, [i] in a diphthong can become [I] or $[\mathrm{e}]$ in fast speech, while $[\mathrm{u}]$ in a diphthong can become [ $\mathrm{\mho}]$ or $[\mathrm{o}]$, depending on the speaker and the speech rate.

The smallest structure of the Mandarin syllable is composed of a single nucleus (V), and the largest consists of four segments (CGVX). Only the vowels /i, u/ (as part of the falling diphthongs) and the nasal consonants /n, y/ can appear in the coda position of a Mandarin syllable.

Tone is a distinctive feature in Mandarin phonology. There are four lexical tones: $\mathrm{T} 1$ is realized as a high tone, $\mathrm{T} 2$ as a mid-rising tone, $\mathrm{T} 3$ as a falling-rising tone and T4 as a high-falling tone (Chao, 1968; Yip, 2002; Duanmu, 2007; Lin, 2007). Examples of the contrasting tones and their pitch contours are presented in Table 5.

Table 5. Examples of tonal contrast in Mandarin

\begin{tabular}{cccccc}
\hline Tone & Pitch contour & Chao numbers & Example & Pinyin & Gloss \\
\hline \hline Tone 1 & High-level & 55 & 妈 & mā & 'mother' \\
Tone 2 & Mid-rising & 35 & 嘛 & má & 'hemp' \\
Tone 3 & Falling-rising & 214 & 马 & mă & 'horse' \\
Tone 4 & High-falling & 51 & 骂 & mà & 'scold' \\
\hline
\end{tabular}

Mandarin tones systematically differ in terms of duration as well. Specifically, Tone 3 is consistently of longer duration than the other three tones in monosyllabic words (Xu, 1997). Tonal contours undergo certain variations conditioned by adjacent 
tones (Chao, 1968; Howie, 1976). Tone 3 is the most complicated tone in the Mandarin tonal system, and a Tone 3 syllable simplifies to a Tone 2 syllable when it is followed by another Tone 3 syllable, a process known as Tone 3 Sandhi. In other words, the initial syllable of Mandarin bisyllabic words is Tone 3 underlyingly but becomes Tone 2 on the surface, as in 你好 /nŭ hău/ (T3-T3) $\rightarrow$ [ni hău] (T2-T3), 'hello'. In addition, Tone 3 is observed to be consistently longer than Tone 2 such that duration is a perceptually relevant acoustic cue for tone distinction and acquisition (Blicher et al., 1990; Chang, 2011).

The main empirical question of the current study is to examine if and how the durational difference across the tones affect the adaptation of Mandarin diphthongs in Chinese Korean.

\section{Mandarin Established Loanwords and On-line Loanwords Adaptation}

There are two ways Mandarin falling diphthongs are realized in loanwords in Chinese Korean: monophthongs and diphthongs. Examples of these two patterns are given in Table 6 and Table 7, respectively. The examples in Table 6 illustrate how Mandarin diphthongs are realized as monophthongs in Chinese Korean, through coalescence or vowel deletion (cf. Casali, 1996). The back glide diphthongs / $\mathrm{au}$, ou/ are realized as /o/ and the front glide diphthongs /ai, ei/ are adapted as $/ \varepsilon /$ and $/ \mathrm{e} /$, respectively. The examples in Table 7 show that Mandarin falling diphthongs are also frequently retained in the loans.

Table 6. Examples of monophthongal realizations

\begin{tabular}{ccccc}
\hline Adaptation & Mandarin & Pinyin & Korean & Gloss \\
\hline \hline /ai/ $\rightarrow / \varepsilon /$ & 代购 & dai4gou4 & $/ \mathrm{t}^{*}$ c.ko/ & 'generation gap' \\
$/ \mathrm{au} / \rightarrow / \mathrm{o} /$ & 号码 & hao4ma3 & $/$ ho.ma/ & 'phone number' \\
$/ \mathrm{ei} / \rightarrow / \mathrm{e} /$ & 煤气 & mei2qi4 & $/ \mathrm{m} \varepsilon$. tsi/ & 'gas' \\
$/ \mathrm{ou} / \rightarrow / \mathrm{o} /$ & 手机 & shou3ji1 & $/ \mathrm{s}^{*}$ o.tsi/ & 'cell phone' \\
\hline
\end{tabular}

Table 7. Examples of diphthongal realizations

\begin{tabular}{ccccc}
\hline Adaptation & Mandarin & Pinyin & Korean & Gloss \\
\hline \hline$/$ ai $/ \rightarrow /$ ai/ & 下载 & xia4zai3 & $/$ sia.tsai/ & 'download' \\
$/ \mathrm{au} / \rightarrow / \mathrm{ao} / 2)$ & 雪糕 & xue3gao1 & $/$ swe.k*ao/ & 'ice cream' \\
$/ \mathrm{ei} / \rightarrow / \mathrm{ei} /$ & 倒需 & dao3mei2 & $/ \mathrm{t}^{*}$ o.mei/ & 'bad luck' \\
$/ \mathrm{ou} / \rightarrow / \mathrm{ou} /$ & 采购 & cai3gou4 & $/ \mathrm{ts}^{\mathrm{h}}$ ai.k*ou/ & 'purchase' \\
\hline
\end{tabular}


This study investigated how bilingual Chinese Korean speakers produce Mandarin loanwords in two different tasks: the production of 1) established loanwords and 2) on-line adaptation of novel loanwords. By examining adaptation patterns in the two tasks, we can see to what extent the input phonetic duration affects the adaptation of diphthongs in existing loanwords and if and how the duration effects are productively extended to novel adaptations. In particular, we explored how the phonetic duration of Mandarin input vowels affects the adaptation patterns. We hypothesized that the longer the duration of the input is, the higher the rate of diphthongal adaptation would be. In other words, if the adaptation is sensitive to the duration of the phonetic input, we expect a higher rate of diphthongal adaptation in phonological contexts where the vowels are longer. Specifically, we examined the effect of Mandarin tone with their varied duration, the position of the target syllable within the word (initial vs. final) and the interaction between the two. We predicted that the longer the tones are, the higher the rate of diphthongal adaptation would be. In terms of the word position, we expected that diphthongal adaptations are more likely to appear in final than initial position since syllables are lengthened in the final position in Mandarin (Barnes, 2006; Chen, 2006). We also examined the interaction between tone and word position. Since Tone 3 shortens in a non-final position in Mandarin (Xu, 1997; Yip, 2002; Wu \& Kenstowicz, 2015), we predicted that the effect of tone on adaptation would differ by the position.

\subsection{Method}

\subsubsection{Participants}

Seven native speakers of Chinese Korean who reside in Dandong, China (three males, four females, age range: $26-69$ years old) participated in the experiment. They were all born, raised and educated in China, speak both Korean and Mandarin, and consider Korean as their native language. No subjects reported any difficulties in speech or hearing. Participant information is summarized in Table 8. The participants provided self-assessments of proficiency in Korean and Mandarin, and

2) According to Lin (2007), the Mandarin /au/ can become [ar] or [ao] in which the second segment becomes lower in height, depending on the speakers and their speech rate in actual articulation. Moreover, for $/ \mathrm{au} /$, the pinyin system uses 'ao' instead of 'au'. As several researchers suggested (Smith, 2006; Vendelin \& Peperkamp, 2006; Paradis \& Lacharité, 2008), orthography might play a role in the adaptation process. Given the acoustic variability of the diphthong and the fact that the adapters are exposed to the pinyin system, an adaptation of /au/ as /ao/ is not unexpected. 
they all rated themselves highly proficient (4-5) in both languages. Also, as part of a larger study, the participants also produced a list of Mandarin words, which were rated for accentedness by a native speaker of Mandarin. The two oldest speakers were rated slightly more accented in their Mandarin compared to the younger speakers.

Table 8. Participant information for the loanword production experiment. proficiency and accentedness ratings are on a scale from 1 (no knowledge/heavily accented) to 5 (perfectly fluent/native-like)

\begin{tabular}{ccccccc}
\hline ID & Gender & Age & $\begin{array}{c}\text { Self-assessed } \\
\text { Korean } \\
\text { proficiency }\end{array}$ & $\begin{array}{c}\text { Self-assessed } \\
\text { Mandarin } \\
\text { proficiency }\end{array}$ & $\begin{array}{c}\text { Mandarin } \\
\text { accentedness } \\
\text { (segmental) }\end{array}$ & $\begin{array}{c}\text { Mandarin } \\
\text { accentedness } \\
\text { (tone) }\end{array}$ \\
\hline \hline P1 & F & 69 & 5 & 5 & 3.5 & 3.5 \\
P2 & M & 69 & 5 & 4 & 3.5 & 3.5 \\
P3 & M & 43 & 5 & 4 & 4 & 4 \\
P4 & F & 41 & 4 & 4 & 4 & 4.5 \\
P5 & M & 31 & 4 & 4 & 4 & 4.5 \\
P6 & F & 30 & 4 & 4 & 4 & 4 \\
P7 & F & 26 & 4 & 4 & 4.5 & 4.5 \\
\hline
\end{tabular}

\subsubsection{Stimuli}

The stimuli for established loanword production consisted of 128 Mandarin words which are commonly used as loan forms in Chinese Korean. The words were chosen based on the loanword list of Ito \& Kenstowicz's (2009a, 2009b) and in consultation with a native speaker of Chinese Korean. The 128 words included 47 instances of target diphthongs /ai, au, ei, ou/ occurring with one of the four tones (drawn from 41 words, since some words have more than one diphthong)3). The distribution of diphthongs by tone and position is summarized in Table 9. Note that it was not possible to balance the distribution of diphthongs across conditions as the selection is limited by available loanwords. For the on-line adaptation task, the stimuli consisted of 91 disyllabic Mandarin words, which are not commonly used as loan forms in Chinese Korean. They are balanced in terms of the number of different diphthong types (/ai, ei, ai, ou/), the tone (Tone $1 \sim$ Tone 4 ), and the syllable

3) One additional diphthong occurs with a neutral tone, which is not included in the analysis. 
position (initial vs. final syllable) of the target diphthong, as summarized in Table 9. The lists of stimuli that were analyzed in the current study are provided in the Appendices A (established loans) and B (on-line adaptation). The Mandarin words and instructions were recorded by a male native speaker of Chinese Korean in his early 20s who also has a native fluency in Mandarin as spoken in Northern China.

Table 9. Distribution of target diphthongs by tone and position: (a) established loans; (b) on-line adaptation. Tone 2 that derives from Tone 3 Sandhi is categorized as Tone 2 and marked in parenthesis.

\begin{tabular}{|c|c|c|c|c|c|c|c|c|c|c|c|c|c|c|c|c|}
\hline \multirow[b]{3}{*}{ Diphthong } & \multicolumn{8}{|c|}{ (a) Established loans } & \multicolumn{8}{|c|}{ (b) On-line adaptation } \\
\hline & \multicolumn{4}{|c|}{ Initial } & \multicolumn{4}{|c|}{ Final } & \multicolumn{4}{|c|}{ Initial } & \multicolumn{4}{|c|}{ Final } \\
\hline & $\mathrm{T} 1$ & $\mathrm{~T} 2$ & $\mathrm{~T} 3$ & $\mathrm{~T} 4$ & $\mathrm{~T} 1$ & $\mathrm{~T} 2$ & $\mathrm{~T} 3$ & $\mathrm{~T} 4$ & $\mathrm{~T} 1$ & $\mathrm{~T} 2$ & $\mathrm{~T} 3$ & $\mathrm{~T} 4$ & $\mathrm{~T} 1$ & $\mathrm{~T} 2$ & $\mathrm{~T} 3$ & $\mathrm{~T} 4$ \\
\hline /ai/ & 1 & 2 & 2 & 5 & 0 & 0 & 1 & 2 & 9 & 3 & 3 & 6 & 3 & 4 & 4 & 5 \\
\hline /au/ & 3 & $3(2)$ & 4 & 5 & 3 & 0 & 2 & 3 & 5 & 4 & 4 & 4 & 4 & 2 & 3 & 4 \\
\hline /ei/ & 0 & 1 & 0 & 0 & 1 & 1 & 0 & 1 & 4 & $4(2)$ & 1 & 6 & 2 & 1 & 2 & 4 \\
\hline /ou/ & 0 & 1 & 1 & 0 & 0 & 1 & 0 & 4 & 4 & 3 & 3 & 4 & 3 & 4 & 4 & 5 \\
\hline
\end{tabular}

The recorded stimuli showed durational differences by the tone in the expected way: Tone $3>$ Tone $1 \& 2>$ Tone 4 . Tone 3 has the longest duration (323ms), Tone 4 has the shortest duration $(234 \mathrm{~ms})$, and Tone 1 and 2 have intermediate durations (300ms and $294 \mathrm{~ms}$, respectively) with the difference between the two not statistically different.

\subsubsection{Procedure}

The loanword recording sessions took place in a quiet hotel room in Dandong, and each session lasted approximately 30 minutes. Both written and oral instructions were provided to ensure that participants fully understood the task. The Mandarin stimuli were presented to the participants aurally along with the Chinese characters on a screen via Microsoft PowerPoint, and the speakers produced appropriate Korean forms embedded in contextually appropriate Korean carrier sentences twice. For example, a participant would hear the Mandarin target word [6iàtsài] ('download'), they would see the target word in Mandarin orthography '下载' and a carrier sentence in Korean orthography 'tten-no-e-seo__ hae-la' ('Do _ _ on the computer.'), as shown in Figure 1. They would then be asked to repeat the target word in its Korean form, embedded in the carrier sentence, twice. During the 
experiment, the subjects could listen to the Mandarin stimuli as many times as they wanted before producing their response. They were asked to produce the sentences aloud at a normal speaking rate, and their speech was recorded with a Zoom H4n recorder and an AT831B microphone. The speech was recorded at a sampling rate of $44 \mathrm{kHz}$.

Sometimes speakers produced two different variants for the same word; in these cases, the variants were counted as two separate tokens. A total of 337 tokens (47 diphthongs $\mathrm{x} 7$ speakers +7 variants) were analyzed for the established loans, and a total of 861 tokens (121 diphthongs $x 7$ speakers +14 variants) were analyzed for the on-line adaptation task.

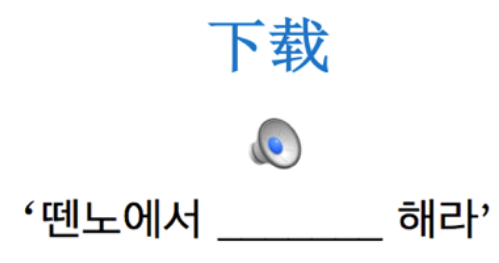

Figure 1. A sample screen display of Mandarin target word and the Korean carrier sentence.

\subsubsection{Transcription}

The recordings were manually transcribed by the first author, a native speaker of Korean with knowledge of Mandarin. The transcriptions were later verified by a male native Korean speaker who has knowledge of Mandarin for a reliability check. There was approximately 90 percent inter-transcriber agreement as to whether the target diphthong was realized as a monophthong or a diphthong in the Korean form, the main question of interest in our study. For the cases of disagreement, the first author rechecked the data and made a decision based on the visual inspection of the formant movement.

Another question that arises in transcription is whether a non-monophthongal realization is, in fact, a true diphthong or a heterosyllabic vowel sequence. The intuition of native speakers of Chinese Korean is fairly clear, and these sequences are true diphthongs in Chinese Korean (Personal communication: Professor Oh, Sung-Ae) and contrast with bisyllabic vowel sequences. 


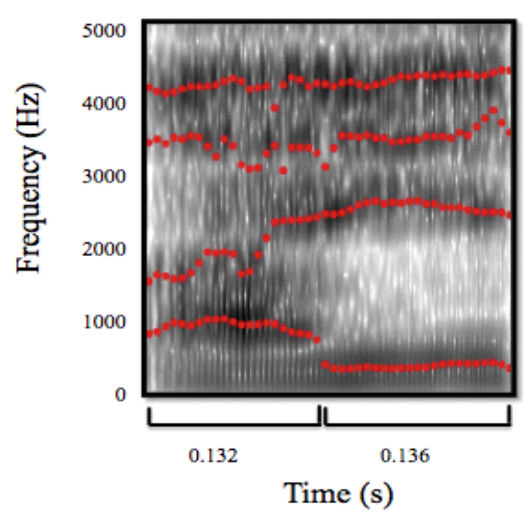

(a) [a.i] in /a.i/ 'baby'

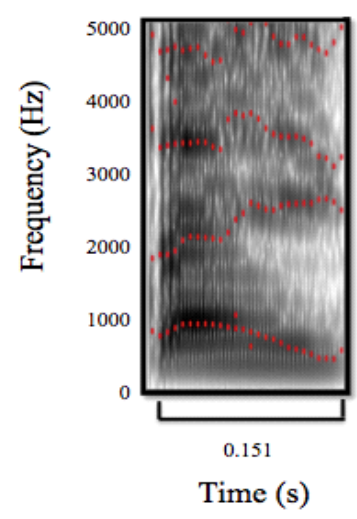

(b) [ai] in /tshăi.kòu/ 'purchase'

Figure 2. (a) A spectrogram of heterosyllabic [a.i] in a native Korean word /a.i/ 'baby' and (b) a spectrogram of diphthongal [ai] in a loanword from Mandarin /tshă i.kòu/ 采购 'purchase' by P7.

While anecdotal, the speech samples produced by the participant P7 illustrate the acoustic difference between diphthongal and heterosyllabic vowel sequences in Chinese Korean. As seen in Figure 2, the diphthong [ai] in a loan form of Mandarin /tshăi.kòu/ 'purchase' is much shorter than the total duration of the native Korean vowel sequence /a.i/: $151 \mathrm{~ms}$ for the Mandarin loanword and $268 \mathrm{~ms}$ for the native Korean word.

\subsubsection{Statistical analysis}

For the statistical analysis, we used a logistic mixed-effects model with the glmer() function of the lme4 package (Bates et al., 2015) in the R Statistical Environment (R Core Team, 2019). For post-hoc comparisons, Wild chi-square tests with the testInteractions ( function of the phia package was used. The dependent variable was the binary choice of diphthongal $(=1)$ vs. monophthongal $(=0)$ realization of target Mandarin diphthongs. The fixed effects predictors included Tone (Tone 1 or 2, Tone 3, and Tone 4), Position (Initial vs. final syllable), Task (Established loans vs. On-line adaptation), and their interactions. Tone is coded as a three-level predictor with Tone 1 and Tone 2 combined into one level because these two tones do not differ significantly in duration. An exploratory analysis found that the adaptation patterns also differ by the diphthong type, and as such, we included Diphthong Type (front 
/ai, ei/ vs. back /au, ou/) as a control predictor. Sum contrast coding was used for all predictors. As for interaction terms, the interaction of Tone * Position was included to test if the variation in tone duration by position is mirrored in adaptation. Recall that Tone 3 syllables are longer than other syllables in the final position, but the Tone 3 shortens in the non-final position (Xu, 1997; Yip, 2002; Wu \& Kenstowicz, 2015), neutralizing the tonal effect on duration. Therefore, we expect that the tone effect will be different depending on whether the syllable is in the final or non-final position. The two-way interactions of Task * Tone and Task * Position were included to test if the effects of tone and position attested in established loans are productively extended to on-line adaptation. The random effects included a random intercept for items and full random slopes for subjects.

\subsection{Results}

\subsubsection{Overview}

The distribution of the adaptation patterns across the two datasets (established loans and on-line adaptations) shows that the monophthongal adaptation is the majority pattern in both datasets. Specifically, the Mandarin diphthongs are monophthongized $79 \%$ and $75 \%$ of the time in the established loanwords and on-line adaptations, respectively; the remaining $21 \%$ and $25 \%$ retain the source language diphthongs.

Recall from section 3.2 that the status of falling diphthongs in Korean phonology is marginal at best. Three of the diphthongs under consideration, /au, ei, ou/, are not attested in native Korean words at all, and /ai/ is marginally available as an archaic variant pronunciation of a front vowel in Chinese Korean (e.g., /kai/ /ke/ 'dog'). The fact that these diphthongs are monophthongized frequently in adaptation is also suggestive of the illicit status of these diphthongs in native phonology. Diphthongal realizations may be considered a case of importation, not unexpected in this bilingual community with a high degree of individual- and community-level bilingualism (Haugen, 1950; Poplack et al., 1988; Paradis \& LaCharité, 2008).

With this overview as a background, we now turn to the effects of phonetic duration on adaptation and examine the effects of Mandarin tone, word position, and their interaction in adaptation. Table 10 summarizes the output of the logistic regression model. 
Table 10. Summary of the output of the logistic mixed-effects models

\begin{tabular}{lcccc}
\hline & Estimate & Std. Error & z-value & $p$-value \\
\hline \hline (Intercept) & -2.639 & 0.837 & -3.151 & $0.002^{* *}$ \\
Task (online vs. established) & -1.358 & 0.92 & -1.476 & 0.140 \\
Position (final vs. initial) & 1.361 & 0.61 & 2.23 & $0.026^{*}$ \\
Tone (tone 4 vs. tone 3) & -2.23 & 0.838 & -2.661 & $0.008^{* *}$ \\
Tone (tone 1\&2 vs. tone 3) & -0.622 & 0.69 & -0.902 & 0.367 \\
Diphthong type (back vs. front) & 4.715 & 0.675 & 6.99 & $<0.001^{* * *}$ \\
Task (online) * Position (final) & -1.871 & 1.151 & -1.626 & 0.104 \\
Position (final) * Tone (tone 4) & -0.591 & 1.42 & -0.416 & 0.677 \\
Position (final) * Tone (tone 1\&2) & -0.295 & 1.301 & -0.227 & 0.821 \\
Task (online) * Tone (tone 4) & 0.92 & 1.494 & 0.616 & 0.538 \\
Task (online) * Tone (tone 1\&2) & -0.173 & 1.408 & -0.123 & 0.902 \\
\hline
\end{tabular}

Significance codes: $<0.001^{* \star * \star},<0.01^{* * *},<0.05^{*}$ ", $<0.1$ '?

Note: The reference level of each predictor variable is underlined. The predictors are sum-contrast coded.

\subsubsection{Tone}

The proportion of diphthongal adaptation by the Mandarin tone in the two tasks is shown in Figure 3. There is a significant main effect of Tone in loanword adaptation. Pairwise comparisons show that Mandarin diphthongs with Tone 3, the longest tone, are more likely to be realized as diphthongs in Chinese Korean than those with Tone 4 , the shortest tone $(p=0.008)$, and a post-hoc test (not shown in the table) show that Tone $1 \& 2$ also induce significantly more diphthongs than Tone 4 , the shorted tone $(p=0.0363)$. The difference between Tone 3 and Tone $1 \& 2$ is in the expected direction (i.e., more diphthongal realizations for Tone 3 than Tone $1 \& 2)$, but this did not reach statistical significance $(p=0.367)$. This finding supports the hypothesis that adapters are sensitive to the input phonetic duration in adaptation. In other words, Chinese Korean bilingual speakers can perceive the different phonetic duration of tones, and this acoustic information affects the adaptation of diphthongs. We found no significant interaction of Tone and Task $(p>0.1)$, indicating that the tonal effects hold in both established loanwords and the on-line adaptation of novel loans. 


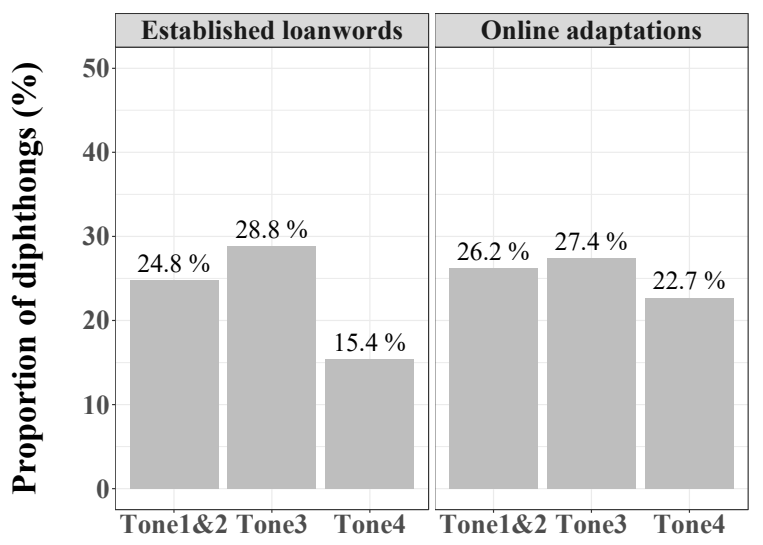

Figure 3. The proportion of diphthongal adaptation by the tone and experimental task.

\subsubsection{Word position}

We now turn to the effects of word position. Word-final lengthening is a cross-linguistically common phenomenon (Barnes, 2006), and the process also applies in Mandarin. Chen (2006) found that final lengthening exists in Mandarin disyllabic words. If the adaptation of diphthongs is sensitive to the phonetic duration of the input vowel, we expect to find a positional asymmetry in adaptation. In established loans, diphthongal adaptation is more likely when the vowel occurs in a word-final syllable compared to a non-final syllable, as shown in Figure 4. This difference can be attributed to the longer duration of vowels in the final than non-final syllables in Mandarin. The position effect, however, does not hold in the on-line adaptation. Statistical tests confirm this observation. There is a main effect of Position in adaptation $(p=0.0267)$, and the interaction of Position and Task is barely marginally significant $(p=0.104)$. Post-hoc tests show that the Position effects hold for established loans $(p=0.0214)$ but not for online adaptation $(p=0.507)$. 


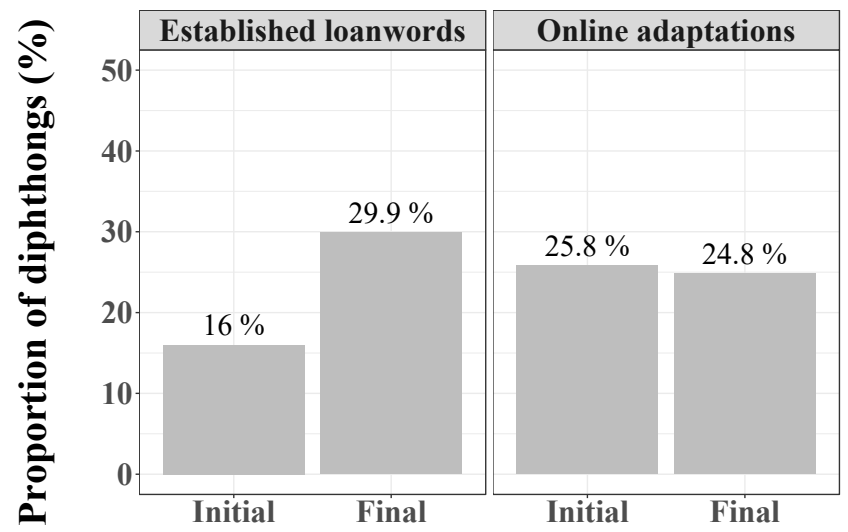

Figure 4. The proportion of diphthongal adaptation by word position and experimental task.

This discrepancy between the two tasks may stem from the difference in the stimuli characteristics used in the experiments. There was a trend of durational differences in the expected direction for the established loans, with vowels in the final syllable showing an overall longer duration than in the initial syllable, while on-line stimuli did not show that difference. However, when the stimuli duration was added as a control predictor to the adaptation model, the interaction of Position * Task still remained significant, suggesting that there may be a difference between the on-line adaptation and the established loans that is not explained by the stimuli duration alone $)^{4}$.

While we remain cautious in interpreting these findings, such a discrepancy between the established loans and on-line adaptation, if more robustly evidenced, would suggest that established loanwords and on-line adaptation reflect different aspects of speakers' knowledge regarding loanwords. Established loanwords are reflections of speakers' lexical knowledge, which is, in turn, the result of the accumulation of collective history of adaptation and subsequent revisions at the community level, and therefore may contain idiosyncrasies and historical remnants of archaic patterns that no longer hold productive. On-line adaptation, on the other hand, reveals speakers' productive knowledge regarding the cross-language correspondence in action. This productive knowledge may itself draw from the generalizations of the

4) The full model with duration added as additional predictor did not converge. The model converged when non-significant interactions (Tone * Position and Tone * Task) and all random slopes were removed from the model. 
existing lexicon, without necessarily being isomorphic to them. Bilingual adapters may internalize the cross-language correspondence pattern, abstracting away from the context-dependent phonetic variation of the input.

Recall from section 4.2.2, however, that the effect of tone duration in established loanwords is mirrored in the on-line adaptation pattern as well. In other words, on-line adaptation selectively projects the effect of phonetic duration conditioned by lexical tones but not by word position. This suggests that the productive generalization speakers draw from the loanword lexicon may be based on tones, a phonological category of Mandarin, rather than directly on the duration. That is, the origin of the tone effect may have been the phonetic durational difference, but the generalization speakers acquire one about tones, not about phonetic duration. However, again, this finding needs further verification through further experimentation with stimuli that are controlled for duration across tasks.

\subsubsection{Interaction of tone and word position}

We now examine how the effect of tone on adaptation interacts with the word position. As mentioned, Tone 3 is substantially shortened to a level comparable to other tones in a non-final position in Mandarin. Thus, if adaptation is sensitive to this tone-by-position interaction in phonetic duration, we predict the same interaction to hold in the diphthongal adaptation rate. Figure 5 shows the breakdown of diphthongal importation rates, separate for tones, positions, and tasks.

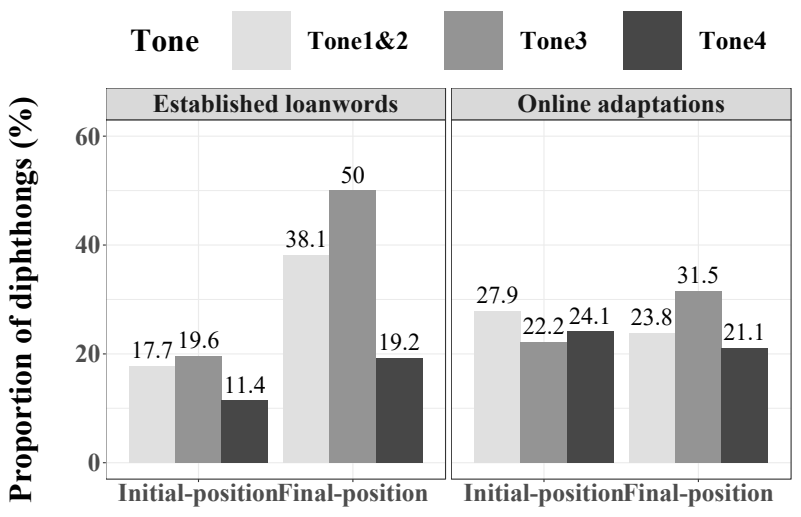

Figure 5. The proportion of diphthongal adaptation by tone, word position, and experimental task. 
Figure 5 presents that the contrast between Tone 3 and other tones, in particular, Tone 4, is larger in the final position than in the initial position. However, statistically, there is no significant interaction of Position and Tone, indicating that tone effects in loanword adaptation do not differ significantly by the word position $(p>0.1)$. The three-way interaction of Tone * Position * Task (in a preliminary model) was also not significant, indicating that there is no evidence that tonal effects on adaptation are any different depending on the position or the task. This finding is compatible with an interpretation that the tone effects are consistent across all conditions. In contrast to the position effect, which may be under-projected to on-line adaptation, the tonal effect seems to persist in on-line adaptation as well as in contexts where the phonetic ground for the tonal effect is reduced, i.e., non-final position. However, the lack of significant interactions may be an issue of statistical power, rather than a lack of genuine effect, and the results need to be interpreted with caution.

One of the unexpected findings of our study is an asymmetrical adaptation of Mandarin diphthongs by vowel quality. The examples in Table 11 illustrate the variation in the adaptation of front unrounded diphthongs /ai/ and /ei/. In many cases, /ei/ and /ai/ tend to be matched with the equivalent diphthongs /ei/ and /ai/ in Chinese Korean. In monophthongal adaptation, /e/ and $/ \varepsilon /$ are the most frequently realized vowels, which retain the [+front] and [-round] features of the /i/ glide and the vowel height of the original nucleus.

Table 11. Examples of adaptation of front diphthongs /ai, ei/

\begin{tabular}{|c|c|c|c|c|}
\hline MA & Pinyin & $\mathrm{CK}$ & Adaptation & Gloss \\
\hline 酸菜 & suan1cai4 & $\begin{array}{l}/ \mathrm{s}^{*} \text { wan.tshai/ } \\
/ \mathrm{s}^{*} \text { wan.tshe/ }\end{array}$ & $\begin{array}{l}\text { /ail } \rightarrow \text { /ai/ } \\
\text { /ai/ } \rightarrow \text { / } /\end{array}$ & 'pickles' \\
\hline 耐克 & nai4ke4 & $\begin{array}{l}\text { /nai. } \mathrm{k}^{\mathrm{h}} \dot{\mathrm{i}} / \\
\text { /ne. } \mathrm{k}^{\mathrm{h}} \Lambda / \\
\text { /nei. } \mathrm{k}^{\mathrm{h}} \Lambda /\end{array}$ & $\begin{array}{l}\text { /ai/ } \rightarrow \text { /ai/ } \\
\text { /ai/ } \rightarrow \text { /e/ } \\
\text { /ai/ } \rightarrow \text { /ei/ }\end{array}$ & 'Nike' \\
\hline 倒霉 & dao3mei2 & $\begin{array}{l}/ \mathrm{t}^{*} \text { o.mei/ } \\
/ \mathrm{t}^{*} \mathrm{o} . \mathrm{me} /\end{array}$ & $\begin{array}{l}\text { /ei/ } \rightarrow \text { /ei/ } \\
\text { /ei/ } \rightarrow \text { /e/ }\end{array}$ & 'bad luck' \\
\hline
\end{tabular}

Table 12 shows examples of back diphthongs /au/ and /ou/. In our data, Mandarin /au, ou/ are most often adapted as /o/, preserving the features [+back] and [+round] of the $/ \mathrm{u} /$ glide and [-high] feature of the nucleus vowel. In addition, when Mandarin / $a \mathrm{u} /$ is preserved as a diphthongal vowel in Chinese Korean, it is often realized as /ao/ rather than / $a u /$. 
Table 12. Examples of adaptation of back diphthongs /au, ou/

\begin{tabular}{|c|c|c|c|c|}
\hline MA & Pinyin & $\mathrm{CK}$ & Adaptation & Gloss \\
\hline 高清 & gaolqing1 & $\begin{array}{l}\text { /k*ao.tshin/ } \\
/ \mathrm{k}^{*} \text { o.tshin/ }\end{array}$ & $\begin{array}{l}\text { /au/ } \rightarrow \text { /ao/ } \\
/ \mathrm{au} / \rightarrow / \mathrm{lo} /\end{array}$ & 'HD' \\
\hline 包子 & baolzi0 & $\begin{array}{l}/ \mathrm{p}^{*} \mathrm{o} . \mathrm{c}^{*} \mathrm{i} / \\
/ \mathrm{p}^{*} \mathrm{O} . . \mathrm{c}^{*} \mathrm{i} /\end{array}$ & $\begin{array}{l}/ \mathrm{au} / \rightarrow \text { /o/ } \\
/ \mathrm{au} / \rightarrow \text { /o:/ }\end{array}$ & 'dumpling' \\
\hline 手机 & shou3ji1 & /s*o.tsi/ & /ou/ $\rightarrow$ /o/ & 'cellphone' \\
\hline 教授 & jiao4shou4 & $\begin{array}{l}/ \mathrm{ts}^{*} \mathrm{o} . \mathrm{su} / \\
/ \mathrm{ts}^{*} \mathrm{o} . \mathrm{so} /\end{array}$ & $\begin{array}{l}/ \mathrm{ou} / \rightarrow \mathrm{/u} / \\
\mathrm{/ou} / \rightarrow \mathrm{/o} /\end{array}$ & 'professor' \\
\hline
\end{tabular}

Figure 6 shows that there is an asymmetry in adaptation patterns across different diphthongs, especially between the front and back diphthongs. Mandarin /ei/ is adapted as a diphthong in about $90 \%$ of the cases in the established loanword, followed by /ai/, /au/ and /ou/. On the basis of the results, the hierarchy of diphthongal adaptation in both tasks is as follows: /ei/ $>/ a i />/ a u />/ o u /$. The rate of diphthong/monophthong choice evidently differs by diphthong type. In particular, there is a large difference between /ou/ and /ei/. This interesting phenomenon will be discussed in more detail in Section 5 .

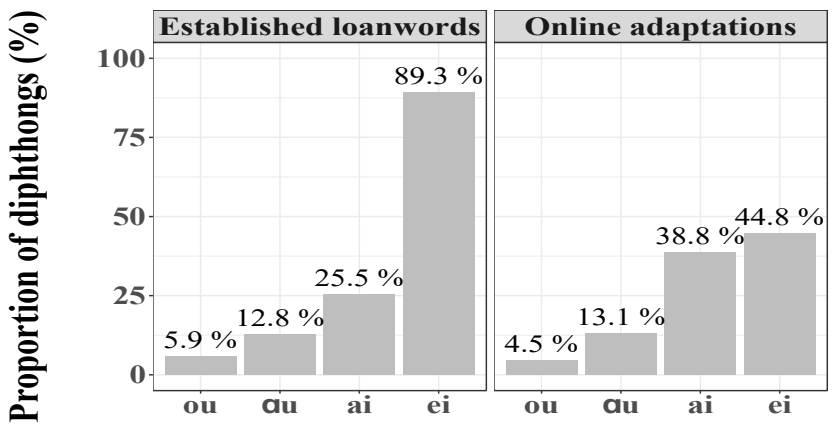

Figure 6. The proportion of diphthongal adaptation by diphthong type.

To sum up, the overall patterns indicate that loanword adaptation is sensitive to the phonetic duration of the input vowel, in particular, the durational difference conditioned by the tone (Tone $3>$ Tone 4 ) and, in the case of established loans, the word position (final > initial) as well. We found a consistent effect of tones across word positions and tasks. We also found that the adaptation is conditioned by the segmental composition of the diphthongs (front unrounded diphthong /ei, ai/ > back rounded diphthongs /au, ao/). 


\section{Discussion}

In this section, we discuss residual issues and implications that arise from the present analysis.

\subsection{The emergence of asymmetrical adaptation among diphthong types}

We found a large difference in the rate of monophthongization between the front and back diphthongs. This is an unexpected finding but a very robust pattern in our data. A phonetic duration-based explanation seems untenable. The duration of our Mandarin stimuli shows no systematic difference between front vs. back diphthongs that would support a duration-based account. In fact, /ei/, which are adapted as diphthong most frequently has the shortest average duration $(266 \mathrm{~ms})$ of all diphthongs, followed by /ou/ (268 ms), /ai/ (287ms), and /au/ (291ms).

We consider a few explanations for this diphthong type effect. First of all, the asymmetry between front and back diphthong adaptation is due to the asymmetry in native Korean phonology. Korean has a front-falling diphthong /ij/, which is a remnant of front-falling diphthongs from Late Middle Korean (H. Kang, 1997; Ahn \& Iverson, 2007). As mentioned above, an archaic pronunciation of some falling diphthongs (/ai/ and / $\Lambda \mathrm{i} /$ specifically) is attested in Chinese Korean (Jin, 2008). In contrast, neither diachronically nor synchronically has Korean had back falling diphthongs.

Another possibility is that the differential treatment of front- and back-final diphthongs is observed in English loanwords in Korean. In Standard Korean, English falling sonority diphthongs are adapted as di-syllabic vowel sequences, similar to Mandarin diphthongs. The only exception is /o $/$, which is always adapted as a monophthong /o/. The examples in Table 13 illustrate this contrast.

Table 13. Examples of English vowel adaptation into Standard Korean

\begin{tabular}{|c|c|c|c|c|c|c|c|}
\hline /aI/ & Gloss & /eI/ & Gloss & /av/ & Gloss & /oø/ & Gloss \\
\hline$/ \mathrm{p}^{\mathrm{h}}$ a.i. $\mathrm{p}^{\mathrm{h}} \mathrm{i} /$ & 'pipe' & /te.i.t. $\mathrm{t}_{\mathrm{i}}$ / & 'date' & /si.k $k^{\mathrm{h}}$ a.u. $\cdot \mathrm{t}^{\mathrm{h}} \dot{\mathrm{i}} /$ & 'scout' & /hom/ & 'home' \\
\hline /ka.i.ti / & 'guide' & /ke.i.t.tit & 'gate' & /a.us/ & 'out' & /kn o.ti / & 'code' \\
\hline /sil.la.i.ti/ & 'slide' & $/ \mathrm{p}^{\mathrm{h}}$ e.i.tsi/ & 'page' & /a.ul.les/ & 'outlet' & $/ \mathrm{p}^{\mathrm{h}}$ o.k $\mathrm{k}^{\mathrm{h}} /$ & 'folk' \\
\hline
\end{tabular}


This pattern is similar to that of Mandarin diphthongs in Chinese Korean, in which the Mandarin diphthong /ou/ has the highest rate of monophthongization. In contrast, the front unrounded vowels /aI/ and /eI/ as well as the back unrounded vowel /aø/ are consistently realized as two vowel sequences in Standard Korean.

The high rate of diphthongal adaptation of Mandarin front unrounded diphthong [ei] also has a parallel in English loans. Interestingly, there is evidence that the English diphthong /eI/ is adapted as a true diphthong in North Kyungsang Korean, which is a pitch accent system, as shown in the examples in Table 14. These diphthongs, unlike disyllabic V.V sequences, act like a long vowel and attract a double high accent. This adaptation pattern is not reported for other English diphthongs.

Table 14. English diphthong /eI/ adaptation in North Kyungsang Korean (Adapted from Kenstowicz \& Sohn 2001)

\begin{tabular}{|c|c|c|c|c|c|c|c|}
\hline & Gloss & & Gloss & & Gloss & & Gloss \\
\hline /péi.pí/ & 'baby' & /thér.púl/ & 'table' & /khér.púl/ & 'cable' & $/ p^{\mathrm{h}} \mathrm{é}^{\prime} \cdot \mathrm{p}^{\mathrm{h}} \dot{\Lambda} /$ & 'paper' \\
\hline
\end{tabular}

In fact, such asymmetry between the front and back diphthongs may have a cross-linguistic phonetic ground. A similar asymmetry is reported for Japanese where Katayama (1998) noted that loanwords from English tend to retain the diphthong [ai] while turning [au] into [a] in Japanese. There is a long-standing observation in the literature (going at least back to Martinet 1952) that back vowels in the vowel space are more contracted and crowded compared to front vowels acoustically.

In addition, an anonymous reviewer brought our attention to Wang (2019)'s study which investigated formant patterns of the four falling diphthongs in Mandarin produced by 102 Beijing native speakers and found that internal representations of falling diphthongs were not completely homogeneous and there were variations on a different degree. In particular, the Mandarin back diphthongs /au/ and /ou/are often monophthongized in younger generations' casual speech. Thus, if Chinese Korean bilinguals have been exposed to monophthongized pronunciations of the back diphthongs in Mandarin, they might be perceived as less distinctive, which makes their diphthongal quality less perceptible than their front counterparts, which in turn affects the adaptation in loans. 


\subsection{Influence of Sino-Korean words}

Another issue is the influence of cognate Sino-Korean words in Mandarin diphthong adaptation. Korean vocabulary consists of a large number of words of Chinese origin, making up about $60 \%$ of the Korean lexicon (Sohn, 1999). SinoKorean words can be expressed in Chinese characters, but the pronunciation of the Chinese characters is different between Mandarin and Korean. For example, the word for 'tofu' is 豆腐 in Mandarin Chinese, which is pronounced /tò.fu/. The Korean word for 'tofu' is Sino-Korean, and Korean uses the same Chinese characters, but it reads as 두부 /tupu/.

Given the availability of Sino-Korean cognates, a question arises as to whether some of the pronunciations of Mandarin loans in Chinese Korean may be based on Sino-Korean pronunciations of the cognate words, rather than a result of sound-based borrowing from contemporary Mandarin. It would be reasonable to suggest that Sino-Korean in the borrowing language may play a role in monophthongal adaptation since the monophthongal output in our data is similar to the Sino-Korean pronunciation of corresponding Chinese characters as shown in Table 15.

Table 15. Comparison of Chinese-Korean loans and Sino-Korean (SK) cognates

\begin{tabular}{|c|c|c|c|c|c|}
\hline Vowel & MA & Pinyin & $\mathrm{CK}$ & Adaptation & Sino Korean cognate \\
\hline /ai/ & 酸菜 & suan1cai4 & $\begin{array}{l}/ \mathrm{s}^{*} \text { uan.ts } \varepsilon / \\
/ \mathrm{s}^{*} \text { uan.tsai/ }\end{array}$ & $/ \mathrm{ai} / \rightarrow / \varepsilon /$ & /san.ts ${ }^{h_{\varepsilon}} /$ \\
\hline /au/ & 号码 & hao4ma3 & /homa/ & $/ \mathrm{au} / \rightarrow \mathrm{/o} /$ & /ho.ma/ \\
\hline /ou/ & 教授 & jiao4shou4 & $\begin{array}{l}\text { /tso.so/ } \\
\text { /tso.su/ }\end{array}$ & $/ \mathrm{ou} / \rightarrow / \mathrm{o}, \mathrm{u} /$ & /kjo.su/ \\
\hline
\end{tabular}

While one cannot rule out the possible influence of Sino-Korean cognates, there are reasons to believe that the monophthongal realization cannot be attributed solely to the Sino-Korean cognates. The evidence comes from "hybrid" forms where in words that contain two diphthongs, one diphthong is realized as a diphthong and the other as a monophthong, as in dao3mei2 倒需 'bad luck' > CK / t*o.mei/. The Sino-Korean transliteration of the same Chinese characters would be /to.me/. This example also illustrates that while the diphthong may monophthongize to a vowel corresponding to the Sino-Korean cognate, the consonants do not follow the Sino-Korean pronunciation, supporting the claim that the monophthongization is a productive adaptation in and of itself rather than a repurposing of Sino-Korean 
pronunciation of the Chinese characters. Thus, one cannot simply assume that monophthongal adaptation is solely due to Sino-Korean cognates. It would, however, be of interest to investigate the influence of Sino-Korean cognates and their relationship with the direct Mandarin borrowings in the future.

\subsection{Sociolinguistic contexts of adaptation}

Recall from section 1 that in Standard Korean, Mandarin falling diphthongs are adapted as hetero-syllabic vowel sequences, as in MA mao2 ze2 dong1 [máu tsá tōy], 'Mao Zedong' > SK /ma.o.ts* ${ }^{\star}$.tuy/. This is in contrast to the patterns found in Chinese Korean, where quite often, the illicit diphthongs are not repaired at all, or they are repaired by monophthongization. We propose that these differences between the two varieties of Korean are attributed to the different levels of contact and bilingualism.

Previous studies have found that the importation of novel structure is more common in the context of high bilingualism than low bilingualism (Haugen, 1950; Paradis \& LaCharité, 2008). Thus, the frequent retention of foreign diphthongs in Chinese Korean is an expected pattern but not in South Korean, where the level of bilingualism is low. The differential repair strategies in the two dialects can also be related to the different levels of bilingualism. Based on a cross-linguistic survey of prosodic adaptation, Kang (2010b) suggests that faithfulness to the input prosodic structure will be more significant in the context of high than low bilingualism. In Chinese Korean, the Mandarin falling diphthongs are adapted as a monosyllabic monophthong or diphthong, preserving the syllable count of the input structure. This is in contrast to the dominant adaptation pattern in the Standard Korean of South Korea, where a falling diphthong is adapted as two separate syllabic nuclei, altering the syllable count of the input structure. To formulate these dialectal differences in Optimality Theoretic terms, we introduce the following constraints in Table 16. 
Table 16. Optimality theory constraints for diphthong adaptation

\begin{tabular}{cc}
\hline Constraint & Explanation \\
\hline \hline \multirow{2}{*}{ FallDiph: } & Avoid falling sonority diphthongs. \\
& $($ e.g. */ai/, */ei/, */ou/, */au/) \\
& Two segments $(\mathrm{V} 1+\mathrm{V} 2)$ of a diphthong cannot be merged into \\
& a vowel sharing features of both $\mathrm{V} 1$ and $\mathrm{V} 2 .($ Casali 1996) \\
& $($ e.g. /ai $/ * / \varepsilon /, / \mathrm{au} / \rightarrow * / \mathrm{o} /)$ \\
Dep-Syl: & Do not add a new syllable. \\
\hline
\end{tabular}

${ }^{*}$ FallDiph is a native phonological constraint against falling diphthongs. ${ }^{*}$ Coalescence is a faithfulness constraint that penalizes the coalescence of segments. Dep-Syl is a prosodic faithfulness constraint that prohibits the addition of a new syllable. The ranking of constraints differs by the level of bilingualism in loanword adaptation. The three different realizations of Mandarin diphthongs and their corresponding constraint rankings are summarized in Table 17.

Table 17. Constraint ranking and differential adaptation strategies in dialects of Korean

\begin{tabular}{lcc}
\hline \multicolumn{1}{c}{ Adapters } & Realization & Ranking \\
\hline \hline & importation & DEP-SYL, *COALESCENCE >> \\
Chinese Korean bilinguals & (diphthong retention) & ${ }^{*}$ FALLDIPH \\
in China & monophthongization & DEP-SYL, *FALLDIPH $>>$ \\
& ${ }^{*}$ COALESCENCE \\
\hline $\begin{array}{l}\text { Monolingual speakers in } \\
\text { South Korea }\end{array}$ & disyllabic split & ${ }^{*}$ FALLDIPH , *COALESCENCE $>>$ \\
\hline
\end{tabular}

In the Chinese Korean community, where the degree of bilingualism is high, the diphthong importation retains the foreign structure and preserves the syllable count at the expense of violating a native phonological constraint. Thus, the ranking is Dep-Syl, ${ }^{*}$ Coalescence $>>$ *FallDiph, as shown in Tableau 1.

Tableau 1. Importation of Mandarin /suan.tshai/ 酸菜 'pickles' into Chinese Korean $/ \mathrm{s}^{\star}$ uan.ts ${ }^{\mathrm{h}} \mathrm{ai} /$

\begin{tabular}{cccc}
\hline /suan.tshai/ & Dep-Syl & ${ }^{*}$ Coalescence & ${ }^{*}$ FallDiph \\
\hline \hline /s*uan.chai/ & & $*$ & \\
/s*uan.che/ & & & \\
/s*uan.cha.i/ & $*$ & & \\
\hline
\end{tabular}


The optimal candidate in Tableau 1 is $/ \mathrm{s}^{*}$ uan.tshai/, which faithfully maintains the prosodic structure of Mandarin phonology and avoids coalescence. On the other hand, the monophthongal adaptation, where the two segments of a diphthong coalesce into a monophthong, obeys the constraint against falling diphthongs in native phonology as seen in Tableau 2.

Tableau 2. Adaptation of Mandarin /6ue.kau/ 雪糕 'ice cream' into Chinese Korean /swe.k*/

\begin{tabular}{cccc}
\hline /6ue.kau/ & Dep-Syl & $*$ FallDiph & $*$ Coalescence \\
\hline \hline /swe.k*o/ & & & $*$ \\
/swe.k*au/ & $*$ & & \\
/swe.k*a.u/ & $*$ & & \\
\hline
\end{tabular}

Note that in both patterns of Chinese Korean, Dep-Syl remains highly ranked, and the prosodic structure of the input (=syllable count) is preserved. Unlike Chinese Korean, in Standard Korean, the Mandarin diphthongs are realized as separate syllabic nuclei, and this repair is possible with Dep-Syl ranked lower than other constraints, as shown in Tableau 3. In other words, this adaptation satisfies the native phonological restriction against falling diphthongs ( ${ }^{*}$ FallDiph) at the expense of altering the prosodic structure of the input (Dep-Syl).

Tableau 3. Adaptation of Mandarin /mau.tsə.toy/ 毛泽东 'Mao Zedong' into Standard Korean /ma.o.ts* ${ }^{*}$.tun/

\begin{tabular}{|c|c|c|c|}
\hline /mau.tsə.tuy/ & ${ }^{*}$ FallDiph & ${ }^{*}$ Coalescence & Dep-Syl \\
\hline /mao.ts*ə.tuy/ & * & & \\
\hline /mo.ts*ə.tuy/ & & * & \\
\hline$\rightarrow /$ ma.o.ts*ə.tup/ & & & * \\
\hline
\end{tabular}

Our finding of divergent repairs and associated roles of input language phonological structure in the two varieties of Korean is also consistent with recent findings that cross-language perception is modulated by listeners' knowledge and experience with the input language (Best \& Tyler, 2007; Bundgaard-Neilson et al., 2011; Nomura \& Ishikawa, 2016; Kwon, 2017). These studies find that experienced listeners of the input language (in our case, Mandarin) tend to show more sensitivity to the input language phonological structure and tend to preserve it better in their 
perception than listeners with limited experience with the input language.

\section{Conclusion}

This paper examined the adaptation of Mandarin diphthongs into Chinese Korean. When Mandarin diphthongs are borrowed into Chinese Korean, two major adaptation patterns are found: monophthongal adaptation and diphthongal importation. About $80 \%$ of the Mandarin diphthongs are realized as monophthongs in Chinese Korean, and the remaining $20 \%$ or so of the Mandarin diphthongs are retained from the source language. This holds in both established loans and on-line adaptation.

The results of this study provide evidence for the role of phonetic information in loanword adaptation against a strictly phonological approach in loanword phonology. It was observed that Chinese Korean bilinguals use the duration of tone in the input language as a phonetic cue when adapting Mandarin words with diphthongs into Chinese Korean. Thus, diphthongs with Tone 4 are more likely than Tone 3 to be realized as monophthongs, since Tone 4 is shorter than Tone 3 in duration. This evidence supports the idea that phonetic detail in the input language plays an important role in loanword adaptation. Furthermore, it was found that word position also has an influence on loanword adaptation. Diphthongal adaptation more likely occurs when the vowel is in a final syllable than in a non-final syllable. We attribute this difference to the longer duration of vowels in final than non-final syllables in Mandarin with longer duration inducing more diphthongal adaptation. The evidence shows that Chinese Korean bilingual speakers use phonetic information such as the duration in the source language in the adaptation process. We found that the tone duration effect is projected into on-line adaptation as well. However, the evidence is less clear on the projection of position effect in on-line adaptation. Such discrepancy may potentially indicate an imperfect projection of phonetic effects to productive knowledge, but a further study where stimuli duration is properly controlled is necessary to provide more clear evidence.

The contextual variation of Tone 3 and its impact on diphthong adaptation is a particularly interesting topic for further study as anonymous reviewers point out. Comparing the phonetic realization of Tone 3 in Sandhi vs. non-Sandhi conditions, as well as underlying Tone 2, and their diphthongal adaptation can help us tease apart the role of surface phonetic duration and the speakers' knowledge of underlying 
tonal categories in adaptation. Do speakers rely on the surface tonal and phonetic realization, or does the underlying tonal category (Tone 3) play a role? In our current data, there are only four Tone 3 Sandhi items (two in each of the established and on-line sets), they were coded as Tone 2 in our analysis. It is interesting to note that Tone 3 Sandhi derived Tone 2 induce more diphthong realization in on-line adaptation (8/13), an expected pattern for Tone 3 , than in established loans $(0 / 14)$. This asymmetry, if borne out in a more controlled study, would be consistent with the idea that in on-line adaptation, phonetic duration effects may be underprojected, and speakers' productive knowledge relies on salient (underlying) phonological categories. However, given the small number of items and lack of proper control, this observation remains anecdotal. An anonymous reviewer points out that while the full Tone 3 is the canonical realization in word-final position, Tone 3 shortening can affect word-final syllables in connected speech. Indeed, what counts as the model phonetic form of adaptation and the extent to which such variation impacts loanword adaptation are interesting and important questions that merit further study. Unexpectedly, we also found asymmetrical adaptations between the front and back diphthongs. The Mandarin back rounded diphthongs / au, ou/ are more likely to be monophthongized than the front unrounded diphthongs /ai, ei/. We considered the potential role of native phonology - availability of front diphthongs but no back diphthongs - and similar asymmetry in English loanwords as an explanation. We also considered the quasi-universal perceptual basis of this asymmetry.

Finally, we examined the cross-dialectal variation in diphthong adaption and situated the findings in the context of how sociolinguistic contexts and the level of bilingualism affects the pattern of loanword adaptation. This study of the vowel adaptation of Mandarin loanwords in Chinese Korean contributes to our understanding of the role of perception/phonetics as well as sociolinguistics in the adaptation process. For future study, we will compare and contrast the adaptation patterns of both established loanwords and on-line adaptations produced by a large number of Chinese Korean adapters and stimuli utilizing both quantitative and qualitative approaches. 


\section{Appendix}

Appendix A. Stimuli for established loanword adaptations

\begin{tabular}{|c|c|c|c|c|}
\hline No & Hanzi & Pinyin & Gloss & Sentence \\
\hline 1 & 保险 & bao3xian3 & insurance & 차를 샀으면 ( )에 들어라. \\
\hline 2 & 号码 & hao4ma3 & number & ( )를 알려줘라. \\
\hline 3 & 开䏌儿 & kai1guanr1 & switch & ( )을 켜라. \\
\hline 4 & 煤气 & mei2qi4 & gas, gas fittings & ( )를 켜서 밥을 해라. \\
\hline 5 & 代购 & dai4gou4 & generation gap & ( )를 해 주는 사람이 많다. \\
\hline 6 & 老板 & lao3ban3 & boss, the responsible supervisor & ( )이 온다. \\
\hline 7 & 老头儿 & lao3tour2 & old male person & ( )이 오신다. \\
\hline 8 & 高清 & gao1qing1 & $\mathrm{HD}$ & ( ) 뗀쓰를 사왔다. \\
\hline 9 & 采购 & cai3gou4 & purchase & 직장에서 ( )하고 있다. \\
\hline 10 & 游戏 & you $2 x i 4$ & game & 아이가 ( )를 많이 한다. \\
\hline 11 & 下载 & xia4zai3 & download & 뗸노에서 ( )해라. \\
\hline 12 & 照顾 & zhao4gu0 & pay attention to & 아이를 ( )해 줘라. \\
\hline 13 & 挂号儿 & gua4haor4 & apply for medical examination & 병원에 가면 ( ) 해야 한다. \\
\hline 14 & 盗版 & dao4ban3 & pirate edition & ( )를 사서 뗀노에 넣었다. \\
\hline 15 & 手机 & shou3ji1 & cell phone & ( )로 전화를 쳐라 \\
\hline 16 & 贷款 & dai4kuan3 & lending; loan & 은행에서 ( )한다. \\
\hline 17 & 回扣 & hui2kou4 & rebate & ( )를 달라. \\
\hline 18 & 电脑 & dian4nao3 & computer & ( )를 써서 일한다. \\
\hline 19 & 菜单 & cai4dan 1 & menu & ( )을 가져와라. \\
\hline 20 & 白干儿 & bai2ganr1 & spirits; liquor & ( )을 많이 마시지 말아라. \\
\hline 21 & 分配 & fen1pei4 & divide & 똑같이 ( )해라. \\
\hline 22 & 成宝 & cheng2bao3 & Chengbao department store & ( ) 초시에 가서 물건 사라. \\
\hline 23 & 面包 & $\operatorname{mian} 4$ baol & bread & ( )가 맛있다. \\
\hline 24 & 馒头 & $\operatorname{man} 2$ tou0 & Chinese-style steamed bread & ( )를 먹어라. \\
\hline 25 & 耐克 & nai4ke4 & Nike & ( ) 신발을 사라. \\
\hline 26 & 倒霉 & dao3mei2 & bad luck & 오늘은 정말 ( )다. \\
\hline 27 & 淘汰 & tao2tai4 & throw away old things & 롱구에서 ( )됐다. \\
\hline 28 & 包子 & baolzi0 & dumpling & ( )가 맛있다. \\
\hline 29 & 白酒 & bai2jiu3 & spirits; liquor & ( )를 마시면 취한다. \\
\hline 30 & 唠嗑儿 & lao4ker1 & chat & 동무들과 ( ) 했다. \\
\hline 31 & 高级 & gaolji2 & high-quality & ( ) 빈관에서 잤다. \\
\hline 32 & 报销 & bao4xiao1 & cost sharing & 단위에서 ( ) 해 준다. \\
\hline 33 & 雪糕 & xue3gao1 & ice cream & ( )를 사먹어라. \\
\hline
\end{tabular}


Appendix A. Continued

\begin{tabular}{cccll}
\hline No & Hanzi & Pinyin & \multicolumn{1}{c}{ Gloss } & \multicolumn{1}{c}{ Sentence } \\
\hline \hline 33 & 雪糕 & xue3gao1 & ice cream & ( )를 사 먹어라. \\
34 & 跑调儿 & pao3diaor4 & out of tune & 노래를 못해 ( )한다. \\
35 & 教授 & jiao4shou4 & professor & ( )에게 배워라. \\
36 & 酸菜 & suan1cai4 & pickles & ( )를 먹어라. \\
37 & 国贸 & guo2mao4 & International trade building & ( )에 가서 물건을 사라. \\
38 & 跑车 & pao3che1 & sport car & ( )가 빠르다. \\
39 & 彩票 & cai3piao4 & lottery ticket & ( )를 사라. \\
40 & 护照 & hu4zhao4 & passport & ( )를 보여줘라. \\
41 & 菜刀 & cai4dao1 & knife & ( )로 배추를 썬다. \\
\hline
\end{tabular}

Appendix B. Stimuli for on-line adaptations

\begin{tabular}{|c|c|c|c|c|}
\hline No & Hanzi & Pinyin & Gloss & Sentences \\
\hline 1 & 改成 & gai3cheng2 & change & 칠을 팔로( ) 한다. \\
\hline 2 & 北非 & bei3fei1 & North Africa & ( )에 가 봤다. \\
\hline 3 & 清炒 & qing1chao3 & fried & 배채를( ) 한다. \\
\hline 4 & 悲愁 & bei1chou2 & sad & 슬픈 드라마 보고( ) 한다. \\
\hline 5 & 颤抖 & chan4dou3 & trembling & 추워서( )한다. \\
\hline 6 & 修改 & xiu1gai3 & modify & 틀려서( )한다. \\
\hline 7 & 炒汇 & chao3hui4 & speculation & 은행에서( )한다. \\
\hline 8 & 解剖 & jie3pou1 & anatomy & 동물을( )한다. \\
\hline 9 & 支配 & zhilpei4 & dominate & 자금을 잘 ( ) 해라. \\
\hline 10 & 妯娌 & zhou2li0 & sister-in-law & 그 사람이 내( )다. \\
\hline 11 & 扣分 & kou4fen1 & deduction points & 시험에서( ) 당했다. \\
\hline 12 & 开办 & kailban4 & start & 유치원을( )한다. \\
\hline 13 & 桃酥 & tao2su1 & peach cake & ( )를 먹고 싶다. \\
\hline 14 & 改道 & gai3dao4 & diverted & 길이 안 좋으니( )해라. \\
\hline 15 & 靠近 & kao4jin4 & near & 위험해서 ( )하지 말아라. \\
\hline 16 & 板材 & ban3cai2 & plate & 건물을( )로 만들었다. \\
\hline 17 & 开采 & kai1cai3 & mining & 산을( )한다. \\
\hline 18 & 战斗 & zhan4dou4 & fighting & ( )에서 죽었다. \\
\hline 19 & 陪伴 & pei2ban4 & accompany & 아이가( ) 필요한다. \\
\hline 20 & 入寇 & ru4kou4 & invade & ( )들이 들어왔다. \\
\hline 21 & 口袋 & kou3dai4 & pocket & 돈을( )에 넣어라. \\
\hline 22 & 带累 & dai4lei3 & involve & ( )해서 미안하다. \\
\hline 23 & 弹头 & dan4tou2 & warhead & ( )를 맞아서 죽었다. \\
\hline
\end{tabular}


Appendix B. Continued

\begin{tabular}{|c|c|c|c|c|}
\hline No & Hanzi & Pinyin & Gloss & Sentences \\
\hline 24 & 被绑 & bei4bang3 & tied & 사장이( ) 됐다. \\
\hline 25 & 走路 & zou3lu4 & walk & 멀지 않으니( )해서 가라. \\
\hline 26 & 地带 & di4dai4 & zone & 여기는 위험한 ( )다. \\
\hline 27 & 皮带 & pi2dai4 & belt & 바지가 크면 ( ) 써라. \\
\hline 28 & 告病 & gao4bing4 & asking for sick leave & 단위에 ( ) 했다. \\
\hline 29 & 栽赃 & zai1zang1 & frame & 사장에게( )했다. \\
\hline 30 & 开炮 & kailpao4 & fire & 시합이( ) 했다. \\
\hline 31 & 白痴 & bai2chi1 & moron & 저 사람은 ( )다. \\
\hline 32 & 该着 & gai1zhao2 & deserve & ( )선생님 칭커한다. \\
\hline 33 & 安培 & an1pei2 & ampere & 전류의 세기는( )를 쓴다. \\
\hline 34 & 头版 & tou $2 \mathrm{ban} 3$ & Front page & 신문( )에 올랐다. \\
\hline 35 & 周报 & zhoulbao4 & weekly & ( )를 봤다. \\
\hline 36 & 被告 & bei4gao4 & defendant & 이 사건에는 저 사람이( )다. \\
\hline 37 & 构成 & gou4cheng2 & constitute & 이 집은 나무로( )됐다. \\
\hline 38 & 胚胎 & pei1tail & embryo & 수업에서( )를 관찰했다. \\
\hline 30 & 沴透 & shen4tou4 & penetration & 물이 방에( ) 됐다. \\
\hline 40 & 该当 & gai1dang1 & deserved & 죄를 지어( ) 감옥에 간다. \\
\hline 41 & 菜豆 & cai4dou4 & kidney bean & ( )을 먹었다. \\
\hline 42 & 理该 & li3gai1 & rationally & 이 일은 네가( ) 책임을 져라. \\
\hline 43 & 头彩 & tou2cai3 & Head color & 채표를 사서( )로 당첨됐다. \\
\hline 44 & 靠近 & kao4jin1 & near & 위험하니( )하지 말아라. \\
\hline 45 & 不周 & bu4zhou1 & not satisfactory & 아이를 보살펴 줬는데( )했다. \\
\hline 46 & 超标 & chaolbiao1 & excessive & 예산이( )했다. \\
\hline 47 & 斑白 & ban1bai2 & gray & 머리카락이( ) 하다. \\
\hline 48 & 才具 & cai2ju4 & talented & ( ) 가 있다. \\
\hline 49 & 开刀 & kaildao1 & surgery & 아파서( )해야 한다. \\
\hline 50 & 案头 & an4tou2 & desk & 책을( )에 놓아라. \\
\hline 51 & 配备 & pei4bei4 & provide, equipment & 기차 안에 뗀쓰를( )했다. \\
\hline 52 & 书包 & shulbao1 & school bag & ( )를 들고 학교에 가라. \\
\hline 53 & 安排 & an1pai2 & arrangement & 빈관을( )해 줘라. \\
\hline 54 & 更改 & geng1gai3 & change & 약속 시간을 ( )하지 말아라. \\
\hline 55 & 贱心 & zei2xin1 & thieves heart & ( )이 있으면 안 된다. \\
\hline 56 & 带电 & dai4dian4 & charged & 뗀쓰가( )돼서 위험하다. \\
\hline 57 & 外逃 & wai4tao2 & fled & 도둑이( )했다. \\
\hline 58 & 薄层 & bao2ceng2 & Thin layer & ( )은 매우 얇다. \\
\hline
\end{tabular}


Appendix B. Continued

\begin{tabular}{|c|c|c|c|c|}
\hline No & Hanzi & Pinyin & Gloss & Sentences \\
\hline 59 & 开口 & kailkou3 & open & 신발이( )됐다. \\
\hline 60 & 白菜 & bai2cai4 & Chinese cabbage & ( )로 김치를 만들었다. \\
\hline 61 & 配菜 & pei4cai4 & side dishes & 주방에서( )한다. \\
\hline 62 & 超拢 & chaolba2 & overtake & 우리 선생님은 재능이( )하다. \\
\hline 63 & 构架 & gou4jia4 & architecture & 이 건물은( )가 좋다. \\
\hline 64 & 眼泡 & yan3pao1 & eyebrows & 잠을 못 자서( )가 부었다. \\
\hline 65 & 剖析 & pou1xi1 & analysis & 어려운 말을( ) 해 줘라. \\
\hline 66 & 剖白 & poulbai2 & explain oneself & 솔직하게( ) 해라. \\
\hline 67 & 保藏 & bao3cang2 & preservation & 과일을 삥샹에( )해라. \\
\hline 68 & 炒家 & chao3jia1 & speculator & 때콴을 못 갚아서( ) 당했다. \\
\hline 69 & 悲惨 & beilcan3 & tragic & 운명이( ) 하다. \\
\hline 70 & 保费 & bao3fei4 & premium & 보호해 줬으니( )를 내라. \\
\hline 71 & 报恩 & bao4en 1 & thanksgiving & 고마우면( )해라. \\
\hline 72 & 难保 & nan 2 bao 3 & hard to protect & 이 일이 잘 될지( )하다. \\
\hline 73 & 煎炒 & jian1chao3 & fried & 이 채소를( ) 해서 먹어라. \\
\hline 74 & 卷轴 & juan3zhou2 & reel & ( )를 열어라. \\
\hline 75 & 非得 & fei1dei3 & have to & 이 일을 ( )해라. \\
\hline 76 & 菜畦 & cai4qi1 & vegetable bed & ( )에서 채소를 기른다. \\
\hline 77 & 北斗 & bei3dou3 & big dipper & 밤새( )를 봤다. \\
\hline 78 & 薄片 & bao2pian4 & sheet & 이 채소를( )으로 잘라라. \\
\hline 79 & 得亏 & dei3kui1 & suffer & ( )사장이 도와줘서 성공했다. \\
\hline 80 & 满口 & man3kou3 & mouthful & 이 사람은( )욕이다. \\
\hline 81 & 被单 & bei4dan1 & bed sheet & ( )을 깨끗하게 빨아라. \\
\hline 82 & 下周 & xia4zhou1 & next week & ( ) 에 놀러 가자. \\
\hline 83 & 扣除 & kou4chu2 & deduction & 월급에서 벌금을( )해라. \\
\hline 84 & 包孕 & baolyun4 & include & 편지에 감정을( )했다. \\
\hline 85 & 口岸 & kou3an4 & port & ( )에 가서 배를 타라. \\
\hline 86 & 炮制 & pao2zhi4 & concocted & 이거와 같이( ) 해라. \\
\hline 87 & 周长 & zhou1chang2 & perimeter & 머리의( )이 얼마냐? \\
\hline 88 & 配备 & pei4bei4 & equipped, equipment & 기차에 뗀쓰를( ) 했다. \\
\hline 89 & 麦胚 & mai4pei1 & wheat germ & ( )를 사 와라. \\
\hline 90 & 开拍 & kailpai1 & shooting & 새 드라마가( )했다. \\
\hline 91 & 采购 & cai3gou4 & buy & 직장에서 ( )하고 있다. \\
\hline
\end{tabular}




\section{References}

Ahn, S. C., \& Iverson, G. K. (2007). Structured imbalances in the emergence of the Korean vowel system. In Salmons, J.C., Dubenion-Smith, S. (Eds.), Historical Linguistics 2005: Selected Papers from the 17th International Conference on Historical Linguistics (Vol. 284, pp. 275-293). Amsterdam \& Philadelphia: John Benjamins Publishing Company.

Barnes, J. (2006). Strength \& weakness at the interface: Positional neutralization in phonetics and phonology. Berlin: Mouton de Gruyter.

Bates D, Mächler M, Bolker B, Walker S (2015). Fitting linear mixed-effects models using lme4. Journal of Statistical Software, 67(1), 1-48.

Best, C. T., \& Tyler, M. (2007). Nonnative and second language speech perception: commonalities and complementarities. In O. Bohn and M.J. Munro (Eds.), Language experience in second language speech hearing: in honor of James Emil Flege (pp. 13-34). Amsterdam: John Benjamins Publishing Company.

Blicher, D. L., Diehl, R. L., \& Cohen, L. B. (1990). Effects of syllable duration on the perception of the Mandarin Tone 2/Tone 3 distinction: Evidence of auditory enhancement. Journal of Phonetics, 18(1), 37-49.

Boersma, P., \& Hamann, S. (2009). Loanword adaptation as first-language phonological perception. In L. Wetzels \& A. Calabrese (Eds.), Studies in Loan Phonology (pp.11-53). Amsterdam: John Benjamins Publishing Company.

Bundgaard-Nielson, R. L., Best, C. T., \& Tyler, M. D. (2011). Vocabulary size matters: The assimilation of second-language australian english vowels to first-language Japanese vowel categories. Applied Psycholinguistics 32(1), 51-67.

Casali, R. F. (1996). Resolving hiatus (Doctoral dissertation). University of California Los Angeles, USA.

Chang, Y. H. S. (2011). Distinction between mandarin tones 2 and 3 for L1 and L2 Listeners. In Proceedings of the 23rd North American Conference on Chinese Linguistics (pp. 84-96), University of Oregon, Eugene, USA.

Chao, Y. R. (1968). A grammar of spoken Chinese. Berkeley \& Los Angeles: University of California Press.

Chen, Y. (2006). Durational adjustment under corrective focus in Standard Chinese. Journal of Phonetics, 34(2), 176-201.

Cheng, C. C. (1973). A synchronic phonology of mandarin Chinese. The Hague: Mouton.

Choi, W. G. (2001). The Korean minority in China: The change of its identity. Development and Society, 30(1), 119-141.

Cui, J. (2011). Investigations and studies on the use of language of Korean nationality discourse community in Dandong area (Master's thesis). Bohai University, China.

Duanmu, S. (2007). The phonology of standard Chinese (2nd ed.,). Oxford: Oxford University Press.

Eychenne, J., \& Jang, T. Y. (2015). On the merger of Korean mid front vowels: Phonetic 
and phonological evidence. Journal of the Korean Society of Speech Sciences, 7, 119-129.

Han, S. (2011). The language identity of Korean-Chinese society in Qungdao, China [in Korean]. Journal of Korean Dialectology, 14, 113-135.

Han, S. (2014). The language change of Korean-chines society in China [in Korean]. Korean Studies, 32, 411-438.

Haugen, E. (1950). The analysis of linguistic borrowing. Language, 26, 210-231.

Howie, J. M. (1976). Acoustical studies of mandarin vowels and tones. Cambridge: Cambridge University Press.

Hsieh, F. F., Kenstowicz, M., \& Mou, X. (2009). Mandarin adaptations of coda nasals in English loanwords. In Calabrese, Andrea; Wetzels, Leo (Eds.), Loanword phonology: Issues and models (pp. 131-154). Amsterdam: John Benjamins Publishing Company.

Ito, C., \& Kenstowicz, M. (2009a). Mandarin loanwords in Yanbian Korean II: Tones. Language Research, 45(1), 85-109.

Ito, C., \& Kenstowicz, M. (2009b). Mandarin loanwords in Yanbian Korean I: Laryngeal features. Phonological Studies, 12, 61-72

Jin, W. (2008). Sounds of Chinese Korean: A variationist approach (Doctoral dissertation). University of Texas at Arlington, USA.

Kang, H. S. (1997). Phonological variation in glides and diphthongs of Seoul Korean: Its synchrony and diachrony (Doctoral dissertation). Ohio State University, USA.

Kang, Y. (2003). Perceptual similarity in loanword adaptation: English post-vocalic wordfinal stops in Korean. Phonology, 20, 219-273.

Kang, Y. (2010a). The emergence of phonological adaptation from phonetic adaptation: English loanwords in Korean. Phonology, 27, 225-253.

Kang, Y. (2010b). Tutorial overview: Suprasegmental adaptation in loanwords. Lingua, 120(9), 2295-2310.

Kang, Y., Han, S., Schertz, J., \& Ryu, N. Y. (2016). A competition of local and supralocal norms in two Chinese Korean dialects: a case study of /y/. Paper presented at New Ways of Analyzing Variation-Asia Pacific 4, Chiayi, Taiwan.

Kang, Y., Schertz, J., \& Han, S. (2015). Vowels of Korean dialects. Poster presented at the 169th Meeting of the Acoustical Society of America, Pittsburgh, USA.

Katayama, M. (1998). Optimality theory and Japanese loanword phonology (Doctoral dissertation). University of California, Santa Cruz, USA.

Kenstowicz, M. (2003). The role of perception in loanword phonology. Studies in African Linguistics, 32, 95-112.

Kenstowicz, M., \& Sohn, H. S. (2001). Accentual adaptation in North Kyungsang Korean. In Michael Kenstowicz (Eds.), Ken Hale: A life in language (pp. 239-270). Cambridge, Mass: MIT Press.

Kwon, H. (2017). Language experience, speech perception and loanword adaptation: Variable adaptation of English word-final plosives into Korean. Journal of Phonetics, 60, 1-19.

LaCharité, D., \& Paradis, C. (2005). Category preservation and proximity versus phonetic 
approximation in loanword adaptation. Language, 36, 223-258.

Lee, K. M., \& Ramsey, S. R. (2011). A history of the Korean language. Cambridge: Cambridge University Press.

Lin, Y. H. (2007). The sounds of Chinese. Cambridge: Cambridge University Press.

Martinet, A. (1952). Function, structure, and sound change. Word, 8(1), 1-32.

Nomura, J., \& Ishikawa, K. (2016). Effects of first language processes and representations on second language perception: The case of vowel epenthesis. Japanese Speakers International Journal of Bilingualism, 22(1), 69-87.

Paradis, C., \& LaCharité, D. (1997). Preservation and minimality in adaptation. Journal of Linguistics, 33, 379-430.

Paradis, C., \& LaCharité, D. (2008). Apparent phonetic approximation: English loanwords in Old Quebec French. Journal of Linguistics, 44, 87-128.

Paradis, C., \& Tremblay, A. (2009). Nondistinctive features in loanword adaptation. Loan phonology (pp. 211-224). Amsterdam: John Benjamins Publishing Company.

Peperkamp, S., \& Dupoux, E. (2003). Reinterpreting loanword adaptations: the role of perception. In Proceedings of the 15th International Congress of Phonetic Sciences (pp. 367-370), Barcelona, Spain.

Poplack, S., Sankoff, D., \& Miller, C. (1988). The social correlates and linguistic processes of lexical borrowing and assimilation. Linguistics, 26, 47-104.

Prince, A., \& Smolensky, P. (1993). Optimality Theory: Constraint Interaction in Generative Grammar. Rutgers University Center for Cognitive Science Technical Report 2. ROA 537-0802.

R Development Core Team. (2019). A language and environment for statistical computing. Available online: https: //www.r-project.org

Schertz, J., Kang, Y., \& Han, S. (2017). Cross-language correspondences in the face of change: phonetic independence vs. convergence in two Korean-Mandarin bilingual communities. International Journal of Bilingualism, 23(1), 157-199.

Shin, J., Kiaer, J., \& Cha, J. (2012). The sounds of Korean. Cambridge: Cambridge University Press.

Silva, D. J., \& Jin, W. (2008). The merger of non-high front vowels in Korean: mission accomplished. Paper presented at the 16th International Conference on Korean Linguistics, Cornell University, Ithaca, USA.

Silverman, D. (1992). Multiple scansions in loanword phonology: Evidence from Cantonese. Phonology, 9, 289-328.

Simonović, M. (2017). Inter-language mappings and why we can't have nice theories about them. Paper presented at the Workshop on Phonetics and Phonology in Loanword Adaptation, Cologne, Germany.

Smith, J. L. (2006). Loan phonology is not all perception: evidence from Japanese loan doublets. In Timothy J. Vance \& Kimberly A. Jones (Eds.) Japanese/Korean linguistics (Vol. 14, pp. 63-74). Palo Alto: CLSI Publications.

Sohn, H. Min. (1999). The Korean language. Cambridge: Cambridge University Press. 
Vendelin, I., \& Peperkamp, S. (2006). The influence of orthography on loanword adaptations. Lingua, 116(7), 996-1007.

Wang, P. (2019). Hanyu putonghua qian xiang erhe yuanyin gongzhen feng moshi de yizhixing biaoxian. [The heterogeneity existing in formant patterns of falling diphthongs in Mandarin Chinese]. Yuyan kexue, 18(3), 299-309.

Wu, F., \& Kenstowicz, M. (2015). Duration reflexes of syllable structure in Mandarin. Lingua, 164, 87-99.

Xu, Y. (1997). Contextual tonal variations in Mandarin. Journal of Phonetics, 25, 61-83.

Yip, M. (1993). Cantonese loanword phonology and optimality theory. Journal of East Asian Linguistics, 9, 261-291.

Yip, M. (2002). Necessary but not sufficient: Perceptual loanword influence in loanword phonology. The Journal of the Phonetic Society of Japan: Special Issue on Aspects of Loanword Phonology, 6, 4-21.

Yoon, T. J., Kang, Y., Han, S., Maeng, H. S., Lee, J., \& Kim, K. (2015). A corpus-based approach to dialectal variation in Korean vowels. In Proceedings of the 18th International Congress of Phonetic Sciences, University of Glasgow, Glasgow, United Kingdom.

Na-Young Ryu

Assistant Teaching Professor

Department of Asian Studies

Pennsylvania State University

102 Old Botany Building, University Park, PA 16802, USA

E-mail: nayoung.ryu@psu.edu

Yoonjung Kang

Professor

Department of Language Studies

University of Toronto Scarborough

1265 Military Trail, MW328, Toronto, On M1C 1A4, Canada

E-mail: yoonjung.kang@utoronto.ca

Department of Linguistics

University of Toronto

100 St. George Street, SS4072, Toronto On M5S 3G3, Canada

Sungwoo Han

Professor 
Department of Korean Language and Literature

Inha University

100 Inha-ro, Michuhol-gu, Incheon 22212, Korea

E-mail: drysoul@inha.ac.kr

Received: July 4, 2020

Revised version received: August 20, 2020

Accepted: August 24, 2020 